\title{
Water Quality of the Weija Reservoir after 28 Years of Impoundment
}

\author{
K. A. Asante*, T. Quarcoopome and F. Y. K. Amevenku \\ CSIR-Water Research Institute, P. O. Box AH 38, Achimota, Ghana \\ *Corresponding author; E-mail: kaasante@chemist.com
}

\begin{abstract}
The water quality of the Weija Reservoir was assessed and the various sources of contaminants were identified in order to provide scientific basis for finding appropriate remedies to the contamination problems that may confront the Reservoir. Monthly water samples were taken from three sampling stations in the Weija Reservoir and analysed for physico-chemical parameters in the laboratory. The mean $p \mathrm{H}$ values of the sampling sites were within the recommended range of $6.5-8.5$ for potability and sustenance of aquatic life. The ionic dominance pattern observed was $\mathrm{Na}>\mathrm{Ca}>\mathrm{Mg}>\mathrm{K}$ and $\mathrm{HCO}_{3}>\mathrm{Cl}>\mathrm{SO}_{4}$, indicating partial cationic characteristics of sea water and anionic characteristics intermediate between fresh water and sea water. Dissolved oxygen (DO) levels were $102.5 \%, 81.5 \%$ and $82.7 \%$ saturation for Weija Intake, Machigani and Galilea, respectively. Thus, the oxygen conditions in the Weija Reservoir were sufficient to support fish and other aquatic life. Maximum BOD level was 8.1 $\mathrm{mg} / \mathrm{l}$ at Weija Intake. Compared with previous studies on the Weija Reservoir, results of the study show a slight increase in nitrate, ammonia, sulphate and phosphate levels. Generally, the levels of nitrate, sulphate, phosphate, trace elements (e.g. manganese and iron) and BOD were moderately high. Anthropogenic activities, such as stone quarrying, dumping of domestic wastes, as well as run-offs from agricultural activities and the occurrence of algae, are some of the sources of contamination identified in the study. Tougher legislation, stricter enforcement of existing regulations, matching of non-technical and technosocial remedial measures and education are among the recommendations made for the protection of the Weija Reservoir.
\end{abstract}

\section{Introduction}

Reservoirs, which are man-made lakes, are vital aquatic ecosystems that serve important environmental and economic purposes, including potable water supply, hydroelectric power generation, irrigation agriculture and fisheries. During the last 4-5 decades, many reservoirs such as Volta, Vea, Barekese, Kpong and Weija have been created in Ghana by damming some rivers. Water supply reservoirs (including Weija Reservoir) in several parts of Ghana ensure adequate and sustainable source of raw water throughout the year for treatment to provide potable water to major cities and towns. The fresh water obtained directly from these reservoirs to satisfy the needs of rapidly growing urban populations are, however, variable in quality due to pollution (DFID, 1999). The main sources of water pollution include indiscriminate disposal of domestic, industrial and municipal solid and liquid wastes; improper land use; poor agricultural practices and environmental degradation.

Previous studies on the limnology of some reservoirs for water production in Ghana include Weija Reservoir (Ansa-Asare, 2001; Ameka et al., 2000; Ansa-Asare \& Asante, 1998; Larmie, 1988; Biney, 1987, 1982; Kpekata \& Biney, 1979; Amuzu, 1975); Barekese Reservoir (Amuzu, 1973); Kpong Headpond (Antwi \& Ofori-Danson, 1993; Biney, 1985). Other available data on the water quality of some inland water systems in Ghana include Ansa-Asare \& Asante (2000), Ampofo (1997), Ansa-Asare (1995, 1992), Biney (1985), Odei (1975) and Ayibotele (1974).

Ansa-Asare \& Asante (1998) compared the nutrient status of the Weija and Kpong reservoirs in Ghana by determining the seasonal indices and interannual changes over a 5-year period from 1993-1997. The nutrient levels and seasonal distribution of nutrients were found to be higher in the Weija Reservoir than the Kpong. Seasonal variation also showed higher levels of nitrates in the rainy season at Weija than at Kpong. The monthly trend of nitrates showed a unique pattern in the months of March and May, the main ploughing periods for farming in the Weija catchment area when most fertilizer is applied. In general, over the 5-year period, there were no trends in nutrient levels. However, sulphates showed a gradual decrease in spatial distribution from 1993-1997, and phosphate index in January at both Weija and Kpong was high.

Bosque-Hamilton et al. (2004) compared Weija, Brimsu and Inchaban reservoirs in Ghana and found that the Weija Reservoir was well mixed and aerated but less transparent with high phytoplankton West African Journal of Applied Ecology - Volume 13 
abundance. The water chemistry showed that cationic pattern of the reservoir waters were similar to sea water due to its proximity to the sea but anionic pattern was intermediate between fresh water and sea water, a trend observed in the present study. The reservoir had more aquatic weeds as evidenced by nutrient dominance with higher nutrient recorded in the wet season. Land use and human activities were identified as principal sources of pollution that greatly influenced the quality of the three reservoirs.

Kpekata \& Biney (1979) looked at the chemistry of the Densu lake between November 1976 and March 1978. They found the $p \mathrm{H}$ and temperature to be within ranges suitable for biological processes and, therefore, congenial to fish life. They reported that the Densu was richer in nutrients, had higher salt content and could be biologically very productive. They, therefore, predicted it would undergo eutrophication faster and become extinct earlier than the Volta lake which had low conductivity. The study concluded that being eutrophic, the Densu lake could support mainly the coarse species of fish, especially those which prefer slightly polluted waters.

The history of aquatic environmental pollution goes back to the very beginning of the history of human civilization (Islam \& Tanaka, 2004). Aquatic pollution has become a global concern, but even so, most developing nations are still producing huge pollution loads and the trends are expected to increase. Knowledge of the pollution sources and impacts on ecosystems is important not only for a better understanding of the ecosystem responses to pollutants but also to formulate prevention measures. Pollution from both domestic and agricultural sources is on the increase. Agricultural activities are reported to contribute about $50 \%$ of the total pollution source of surface water by means of the higher nutrient enrichment, mainly ammonium ion $\left(\mathrm{NH}_{4}\right)$ and nitrate $\left(\mathrm{NO}_{3}\right)$, derived from agricultural input (Islam \& Tanaka, 2004).

The assessment of water quality in reservoirs is essential because reservoirs are often one of the main sources of water for human consumption and irrigation. From the foregoing, it has become imperative to assess the quality of the water supply from reservoirs and identify the various sources of contaminants in order to ascertain the contamination problems that may confront the reservoirs and provide scientific basis for finding appropriate remedies to the situation and its inherent impacts on human populations that depend on the reservoirs. It is in this light that the present study was undertaken in the Weija Reservoir.

\section{Study area}

The Weija Reservoir (Fig. 1) ( $0^{\circ} 20^{\prime} \mathrm{W} 0^{\circ} 25^{\prime} \mathrm{W}$ and $\left.5^{\circ} 30^{\prime} \mathrm{N} 5^{\circ} 45^{\prime} \mathrm{N}\right)$ was created in 1977 as a replacement for an earlier one which was washed away in 1968 by Ghana Water Company Limited (GWCL) through damming River Densu mainly to satisfy the demand for potable water supply. The Weija Reservoir, located about $17 \mathrm{~km}$ west of Accra, is almost at the mouth of the $116 \mathrm{~km}$ long River Densu which takes its source from the Atewa-Atwiredu mountain range in the Eastern Region of Ghana. The current reservoir provides water to western parts of Accra, supports irrigation projects, as well as fisheries.

The Weija Reservoir is $14 \mathrm{~km}$ long, $2.2 \mathrm{~km}$ wide and has total surface area of $38 \mathrm{~km}^{2}$ with mean depth of $5 \mathrm{~m}$ (Vanden Bossche \& Bernacsek, 1990). The normal surface elevation is estimated at $14.37 \mathrm{~km}$ with maximum of $15.24 \mathrm{~km}$ (Nukunya \& Boateng, 1979). The reservoir area is low lying with undulating topography and isolated ridges. Climatic conditions are tropical with temperature averaging $27{ }^{\circ} \mathrm{C}$. Rainfall is moderate with the seasonal average being $65.5 \mathrm{~mm}$. The catchment of the reservoir lies in the coastal savanna zone where rainfall is seasonal, with two rainfall peaks in June and September, while dry periods span between December and March. The main economic activities in the catchment are fishing and crop farming. Major crops include maize, cassava, sugarcane and vegetables. Untreated domestic waste waters are discharged into the Reservoir.

\section{Sampling}

\section{Materials and methods}

West African Journal of Applied Ecology - Volume 13 
The study was conducted in 2005 and covered three sampling stations, namely Weija Dam Intake, Machigani and Galilea. Sampling was mainly confined to the mid portion of the water course, and each station was sampled 10 times in the year, from March to December. All the water samples were taken with a water sampler. The reservoir was sampled under base flow conditions, about $20-30 \mathrm{~cm}$ deep from the surface.

\section{Methods for physico-chemical analyses}

Water samples for physico-chemical analyses were collected directly into clean 1-litre plastic bottles. Temperature and $p \mathrm{H}$ were measured in situ, using mercury-in-glass thermometer and portable $p \mathrm{H}$ meter, respectively. For dissolved oxygen (DO) determinations in the laboratory, separate samples were collected into plain glass bottles and the DO fixed, using the azide modification of the Winkler's method (APHA, 1998). Samples for biochemical oxygen demand (BOD) were collected into dark painted glass bottles and were incubated at $20^{\circ} \mathrm{C}$ for 5 days before the remaining DO determined. All the samples were stored in cold boxes and, on return to the laboratory, analysed for physico-chemical constituents. Physicochemical parameters determined at the sites and on collected water samples formed the basis of assessing the quality of the reservoir water. The laboratory analyses were undertaken according to procedures outlined in the Standard Methods for the Examination of Water and Wastewater, 20th edition (APHA, 1998).

\section{Statistical analysis}

Statistical analysis was performed using SPSS (version 12.0, SPSS Inc., Chicago, Il, USA) for Windows, 2003. One half of the values of the detection limit was substituted for values below the limit of detection and used in the statistical analysis. Since most concentrations were not normally distributed, non-parametric analysis was performed. Mann-Whitney $U$-test was used to determine differences in concentrations among the three sampling stations. A probability value of $P<0.05$ was considered as statistically significant in the study.

\section{Physical parameters}

\section{Results and discussion}

Reservoirs in developing countries are special case of river pollution because of poor pollution control which subjects them to more indiscriminate pollution and poor planning, coupled with poor enforcement of land-use plans, which lead to encroachment of watersheds by human settlements, agricultural activities and industrial establishment. Results of the physico-chemical analyses (Table 1) are compared with both the World Health Organization (WHO) guidelines for drinking water (WHO, 1984, 1993, 1996, 2004) and the international average for fresh water since communities within the catchment area of the Weija Reservoir use the untreated water for domestic purposes. The concentrations that are above the guideline values are identified and discussed. The mean and range of $p \mathrm{H}$ values of the sampling stations namely Weija Intake (8.45, 7.7-9.9), Machigani (7.97, 7.6-9.0) and Galilea (8.01, 7.1-9.0) were within the recommended range of 6.5-8.5 for potability (WHO, 1984) and sustenance of aquatic life. Differences in values of $p \mathrm{H}$ between Weija Intake and Galilea were statistically significant $(P=0.049)$ (Fig. 2). The relatively higher $p \mathrm{H}$ values for the intake sampling station could result from increased human activities leading to high photosynthesis and higher $p \mathrm{H}$.

The type and concentration of suspended matter influence the turbidity and transparency of water. In the present study, mean turbidity values recorded were 20, 18 and 16 NTU (Nephelometric Turbidity Unit) for Weija Intake, Machigani and Galilea, respectively. These values exceeded the WHO guideline value of $5 \mathrm{NTU}$ and could be due to soil erosion which is especially high in the rainy season, as well as the occurrence of algae and water weeds. Rains cause flooding which then results in the transport of nutrient detritus, silt and industrial and domestic wastes into the reservoir. Webb (1960) pointed out that West African Journal of Applied Ecology - Volume 13 
rainfall in the tropics is more important than temperature in determining environmental quality. The variation between wet and dry season turbidity values were statistically significant $(P=0.047)$. The relatively higher value for the wet season could be attributed to land runoff. During the wet season, urban runoff may have introduced high loads of suspended matter into the water system.

The ionic content measured by conductivity was higher in the Weija Reservoir (mean value of 408 $\mu \mathrm{S} / \mathrm{cm}$ ) compared to a study on the Volta lake (mean value of $79 \mu \mathrm{S} / \mathrm{cm}$ ) (Ofori-Danson \& Ntow, 2005). Conductivity, however, did not exhibit pronounced temporal variation between dry and wet seasons. The ionic dominance for water bodies according to Stumm \& Morgan (1981) are: $\mathrm{Ca}>\mathrm{Mg}>\mathrm{Na}>\mathrm{K}$ and $\mathrm{HCO}_{3}>\mathrm{SO}_{4}>\mathrm{Cl}$ for fresh waters, and $\mathrm{Na}>\mathrm{Mg}>\mathrm{Ca}>\mathrm{K}$ and $\mathrm{Cl}>\mathrm{SO}_{4}>\mathrm{HCO}_{3}$ for waters of marine origin. Generally, the ionic dominance pattern observed in the study was $\mathrm{Na}>\mathrm{Ca}>\mathrm{Mg}>\mathrm{K}$ and $\mathrm{HCO}_{3}>$ $\mathrm{Cl}>\mathrm{SO}_{4}$. These cations, except potassium, were in relatively high concentrations compared with some other fresh waters (Table 2). Soils in the Weija catchment are sodium uleisols, coastal savanna, ochrosols and lithosols (Ayibotele \& Tuffour-Darko, 1979; Ahn, 1970). The Reservoir, on account of its proximity to the sea, partially showed cationic characteristics of sea water. The anions were, however, an intermediate of fresh water and sea water. The dominance of chloride (mean concentration of $48.6 \mathrm{mg} / \mathrm{l}$ ) over sulphate may be due to the proximity of the Weija Reservoir to the coast leading to a strong atmospheric maritime aerosol inputs together with fertilizer from agricultural, as well as domestic origins. There was a significant difference in chloride concentrations between wet and dry seasons $(P=0.005)$ with the dry season showing relatively higher values (mean $51.5 \mathrm{mg} / \mathrm{l}$ ) than the wet season (mean 44.2 $\mathrm{mg} / \mathrm{l})$ probably due to evapotranspiration.

TABLE 2

Average ionic composition of surface water of some water bodies $(\mathrm{mg} / \mathrm{l})$

$\begin{array}{lrrll}\text { Ion } & \begin{array}{l}\text { Weija Reservoir } \\ \text { (This study) }\end{array} & \begin{array}{l}\text { Lake Volta } \\ \text { (Ghana) }\end{array} & \begin{array}{l}\text { Lake Kariba } \\ \text { (Zimbabwe/Zambia) }\end{array} & \begin{array}{l}\text { African fresh } \\ \text { water }\end{array} \\ \mathrm{Na}^{+} & 38.4 & 12.1 & 3.6 & 11.0 \\ \mathrm{~K}^{+} & 2.3 & 9.6 & \text { No data } & \text { No data } \\ \mathrm{Ca}^{2+} & 18.4 & 9.4 & 9.3 & 12.5 \\ \mathrm{Cl}^{-} & 48.6 & 7.1 & \text { No data } & \text { No data } \\ \mathrm{Mg}^{2+} & 10.1 & 1.6 & 1.9 & 3.8\end{array}$

Source: Lake Volta (Ofori-Danson and Ntow, 2005); Lake Kariba (Marshall, 1984); African fresh water (Livingstone, 1963).

Compared with the international average value of $<100 \mathrm{mg} / \mathrm{l}$ for fresh water (Meybeck \& Helmer, 1989), relatively higher TDS values were recorded for the Weija Reservoir (mean of $224 \mathrm{mg} / \mathrm{l}$ ). This could be due to ionic and nutrient enrichment from agricultural land drainage. Total alkalinity averaged $104 \mathrm{mg} / \mathrm{l}$ and this could be as a result of the contribution of carbonates and bicarbonates. Higher total alkalinity indicates higher buffering capacity since total alkalinity is known to buffer $p \mathrm{H}$ changes that occur naturally as a result of photosynthetic activity of plants (Wetzel, 1983).

The Weija Reservoir is adequately oxygenated, with dissolved oxygen (DO) levels of $102.5 \%, 81.5 \%$ and $82.7 \%$ saturation for Weija Intake, Machigani and Galilea, respectively. These values are higher than the minimum $\left(30 \%, 2.43 \mathrm{mg} / 1 \mathrm{DO}\right.$ at $\left.25.1^{\circ} \mathrm{C}\right)$ required for protection of aquatic life (DeZuane, 1997). The high DO levels maintained in the waters of the Weija Reservoir could be ascribed to mixing and reaeration due to wind action (Straskaba \& Tundisi, 1999), as well as photosynthetic activity. Thus, the oxygen levels in the Weija Reservoir were above the $5 \mathrm{mg} / \mathrm{l}$ threshold needed to support fish life (Hynes, 1970). Relatively higher DO levels were registered in the wet season. This was due to the inflow of cool oxygenated flood waters from the catchment area. The inflow is an annual event that normally occurs from May to August, a phenomenon which was also reported by Ameka et al. (2000). Statistically, there were significant differences in DO between Weija Intake and Machigani $(P=0.001)$ and between Weija Intake 
and Galilea $(P=0.014)$ (Fig. 3). The differences may be attributed to the different rates of photosynthetic activity at the sites.

Mean biochemical oxygen demand (BOD) levels recorded for the Weija Intake, Machigani and Galilea were $4.5 \mathrm{mg} / \mathrm{L}, 3.5 \mathrm{mg} / 1$ and $4.3 \mathrm{mg} / \mathrm{l}$, respectively, and there was no significant difference between the wet $(4.0 \mathrm{mg} / \mathrm{l})$ and dry $(4.1 \mathrm{mg} / \mathrm{l})$ season values. This implies that seasons did not have significant influence on BOD. This observation may suggest that organic pollutants that account for BOD in the Reservoir are discharged at rates that are proportional to the discharges of the river into the Reservoir.

\section{Nutrients}

Though the natural background levels of phosphate $\left(\mathrm{P}^{-} \mathrm{PO}_{4}{ }^{3-}\right)$ in inland waters usually range from 0.005 to $0.05 \mathrm{mg} / \mathrm{l}$ (Dunne \& Leopold, 1978), the mean $\mathrm{P}_{-} \mathrm{PO}_{4}{ }^{3-}$ contents at all the three stations in the Weija Reservoir were in excess of $0.1 \mathrm{mg} / \mathrm{l}$ (Table 1). This could result from the washing of cars, clothing, etc., and bathing by both children and adults in the Reservoir at each sampling site as witnessed during the study. Ammonia is known to be toxic to aquatic life (especially fish) even at very low concentrations (McNeely et al., 1979) and can cause odour and taste problems at concentrations above 1.5 and $35 \mathrm{mg} / \mathrm{l}$, respectively (WHO, 1996). At all the three stations, concentrations of ammonium were below the lower limit.

Nitrate levels were grossly exceeded considering the global average of $0.1 \mathrm{mg} / \mathrm{l}$ for nitrate in fresh water (Meybeck \& Helmer, 1989). This could be as a result of runoff from fertilized farm lands and domestic wastes. Concentrations measured were $0.48,0.27$ and $0.45 \mathrm{mg} / \mathrm{l}$ for Weija Intake, Machigani \& Galilea, respectively. The Reservoir was enriched in nitrogen nutrients as evidenced by the occurrence of algal blooms during periods of high waters and supported by the fact that inorganic nitrogen in excess of $0.3 \mathrm{mg} / \mathrm{l}$ is known to cause algal blooms. The concentrations of sulphate also grossly exceeded the average of $4.8 \mathrm{mg} / \mathrm{l}$ for fresh water (Meybeck \& Helmer, 1989). Mean concentrations measured were 21.6 $\mathrm{mg} / \mathrm{l}$ (Weija Intake), $13.2 \mathrm{mg} / \mathrm{l}$ (Machigani) and $14.3 \mathrm{mg} / \mathrm{l}$ (Galilea) (Fig. 4). It may, thus, be inferred that sulphate is abundant in the Weija Reservoir.

\section{Trace elements}

Manganese $(\mathrm{Mn})$ is a common problem element in natural waters. In drinking waters, this element may cause unsightly stains and produce a brown/black precipitate. Although it is an essential element, the chronic ingestion of $\mathrm{Mn}$ in drinking water is associated with neurological damage (Kondakis et al., 1989). In the present study, mean levels of Mn measured were $0.194 \mathrm{mg} / \mathrm{l}$ (Weija Intake), $0.155 \mathrm{mg} / \mathrm{l}$ (Machigani) and $0.176 \mathrm{mg} / \mathrm{l}$ (Galilea), far in excess of the average of $0.01 \mathrm{mg} / \mathrm{l}$ for fresh water (Meybeck \& Helmer, 1989). In relation to the WHO guideline value of $0.40 \mathrm{mg} / \mathrm{l}$ for $\mathrm{Mn}$ in drinking water (WHO, 2004), the levels measured in this study were lower. The concentrations of iron $(\mathrm{Fe})$, were $0.735 \mathrm{mg} / \mathrm{l}$, (Weija Intake), $0.587 \mathrm{mg} / \mathrm{l}$ (Machigani) and $0.687 \mathrm{mg} / \mathrm{l}$ (Galilea) (Fig. 5). These levels also exceeded the iron average of $0.01 \mathrm{mg} / \mathrm{l}$ for fresh water (Meybeck \& Helmer, 1989).

The WHO guideline value of $0.30 \mathrm{mg} / \mathrm{l}$ for Fe in drinking water (WHO, 2004) was exceeded by $90 \%$, $80 \%$ and $80 \%$ for the Weija Intake, Machigani and Galilea, respectively. This could be ascribed to high levels of iron in the soils. Thus, it could be inferred from Fig. 5 that iron is abundant in soils of the catchment area as in all the three sampling stations; iron levels far exceeded that of Mn. Fig. 6 presents mean concen-trations of selected parameters from the three sampling sites and, except for nitrate nitrogen, phosphate and Mn, concentrations were almost the same for the three sites.

\section{Comparison with previous studies on the same water body}

A chronology of some hydrochemical studies of the Weija Reservoir (Table 3) shows that, apart from the intake sampling point which runs through all the studies, the other sampling stations were not the same for the various studies and this could account for some of the differences observed. Also the study by Ansa-Asare \& Asante (1998) only looked at the nutrient status. It can be seen that $p \mathrm{H}$ has remained

West African Journal of Applied Ecology - Volume 13 
almost neutral due to the buffering capacity of the Reservoir as reflected in total alkalinity values. Total dissolved solids (TDS) in this study showed relatively high values compared with the study in 1997 by Bosque-Hamilton et al. (2004). This could arise from the continuous discharge of silt-laden runoffs. Chloride, sodium, potassium, calcium, total hardness and bicarbonate values have more or less become stable over the years. Dissolved oxygen (DO) has shown a dramatic increase judging from the 1978 study by Kpekata \& Biney (1979).

Apart from photosynthetic activity, eutrophication is now a common occurrence in the Weija Reservoir and this could be a contributing factor to the high DO levels since plants take in carbon dioxide and give out oxygen during photosynthesis. Biochemical oxygen demand (BOD) which also gives indication of the level of pollution rose from $3.8 \mathrm{mg} / \mathrm{l}$ in 1978 to $8.1 \mathrm{mg} / \mathrm{l}$ in 1998 . This study also recorded a maximum BOD of $8.1 \mathrm{mg} / \mathrm{l}$. For unpolluted waters, BOD values should range from about 1-3 mg/l. BOD results in this present study, therefore, indicate some degree of pollution possibly as a result of sewage discharge and runoff from agricultural activities. The practice of direct dumping of solid wastes and discharge of sewage effluents into streams has been identified as contributing to enhance BOD levels in streams (Sangodoyin \& Sanyalou, 1995). The gradual increase of nitrate, ammonia, sulphate and, to a lesser extent, phosphate over time attests to the gradual deterioration of the water quality of the Weija Reservoir.

\section{Conclusion and recommendations}

The mean $p \mathrm{H}$ values of the sampling sites were within the recommended range of $6.5-8.5$ for potability and sustenance of aquatic life. Predominantly, the ionic dominance pattern observed were $\mathrm{Na}>\mathrm{Ca}>\mathrm{Mg}$ $>\mathrm{K}$ and $\mathrm{HCO}_{3}>\mathrm{Cl}>\mathrm{SO}_{4}$, indicating partial cationic characteristics of sea water and anionic characteristics intermediate between fresh water and sea water. Dissolved oxygen levels in the Weija Reservoir were found to be in concentrations sufficient to support fish and other aquatic life. BOD level of 8.1 $\mathrm{mg} / \mathrm{l}$ in this study reflects some degree of pollution.

Levels of iron exceeded the WHO guideline value of $0.30 \mathrm{mg} / \mathrm{l}$ for Fe in drinking water by $90 \%, 80 \%$ and $80 \%$ for the Weija Intake, Machigani and Galilea, respectively. Mean levels of Mn measured were far in excess of the average of $0.01 \mathrm{mg} / \mathrm{l}$ for fresh water, while in relation to the WHO guideline value of 0.40 $\mathrm{mg} / \mathrm{l}$ for $\mathrm{Mn}$ in drinking water, the levels measured in this study were low. Compared with previous studies on the Weija Reservoir, this study shows a gradual increase in nitrate, ammonia, sulphate and phosphate levels over time. Generally, the levels of nitrate, sulphate, phosphate, trace elements (e.g. manganese and iron) and BOD were moderately high, indicating organic contamination, nutrient enrichment and gradual deterioration of the water quality in the Weija Reservoir.

Some of the pollutants are non-degradable, can bioaccumulate in the tissues of aquatic organisms and enter the food chain with dangerous consequences for the ecosystem and humans as final consumers in the food chain. This, therefore, calls for the enforcement of existing laws and/or promulgation of tougher legislation against improper disposal of urban wastes and the release of untreated wastes/effluents into water bodies to ensure sustainable environment. Although the Rreservoir could have self-cleansing capacity, the capacity could be strained by persistent pollution overloads. This is attributable to its being flanked by expanding human habitats and vibrant socio-economic activities.

Matching of non-technical and techno-social remedial measures is recommended. These include sensitization of polluters on merits of environmental protection practices such as cleaner production and strict enforcement of environmental protection laws. Another important issue for pollution mitigation measures pertains to the need to educate all stakeholders such as the perpetrators, the affected, policy and legal authorities, river basin management boards, and other interested parties, and include them in planning and decision making exercises.

\section{Acknowledgement}

West African Journal of Applied Ecology - Volume 13 
The authors wish to express their sincere thanks to the Director of CSIR-Water Research Institute for his interest and support, and also to Messrs Sampson Kwadwo Abu, Nicholas Anawoe and Emmanuel AduOfori for their technical assistance during sampling and analyses.

\section{References}

Ahn P. M. (1970). West African Soils. Oxford University Press, London.

Ameka G. K., de-Graft Johnson K. A. A. and Akuamoah R. K. (2000). A review of the chemical status of the Weija Lake. J. Ghana Sci. Ass. 2: 136-147.

Ampofo J. A. (1997). A survey of microbial pollution of rural domestic water supply in Ghana. Int. J . Envir. Hlth Res. 7: 121130.

Amuzu A. T. (1973). Some aspects of the limnology of Lake Barekese in the Ashanti Region of Ghana. Ghana Water and Sewerage Corporation, Accra.

Amuzu A. T. (1975). A survey of the water quality of the River Densu. Water Resources Research Unit. Accra, Ghana. $57 \mathrm{pp}$.

Ansa-Asare O. D. (1992). Limno-chemical characterization and water quality assessment of River Densu. IAB Technical Report No. 132, Accra, Ghana. 40 pp.

Ansa-Asare O. D. (1995). Limno-chemical characterization and water quality assessment of Birim basin. IAB Technical Report No. 159, Accra, Ghana. 25 pp.

Ansa-Asare O. D. (2001). Land-based sources of pollution and environmental quality of Weija Lake. J. Ghana Sci. Ass. 3: 100108.

Ansa-Asare O. D. and Asante K. A. (1998). A comparative study of the nutrient status of two reservoirs in southeast Ghana. Lakes and Reservoirs: Res. Mgmt 3: 205-217.

Ansa-Asare O. D. and Asante K. A. (2000). The water quality of the Birim River in South-east Ghana. West Afr. J. appl. Ecol. 1: $23-34$.

Antwi L. A. K. and Ofori-Danson P. K. (1993). Limnology of a tropical reservoir (The Kpong Reservoir in Ghana). Trop. Ecol. 34: 75-87.

APHA, AWWA, WEF. (1998). Standard Methods for the Examination of Water and Wastewater, 20th edn. Washington, D.C.

Ayibotele N. B. (1974). A preliminary water balance of the Densu and Ayensu river basins. WRRI Technical Report No. 6996, Accra, Ghana. 97 pp.

Ayibotele N. B. and Tuffour-Darko T. (1979). Sediment loads in the southern rivers of Ghana. Water Resources Research Institute, Accra, Ghana. pp. 15-25.

Biney C. A. (1982). Preliminary survey of the state of pollution of the coastal environment of Ghana. Oceanologica Acta. SP: 39-43.

Biney C. A. (1985). Preliminary physico-chemical studies of estuaries along the Gulf of Guinea in Ghana. Trop. Ecol. 26 : $22-31$.

Biney C. A. (1987). Changes in the chemistry of a tropical man-made lake, the Densu Reservoir, during five years of impoundment. Trop. Ecol. 28: 222-231.

Bosque-Hamilton E. K., Nana-Amankwaa E. and Karikari A. Y. (2004). A preliminary comparative limnological assessment of three coastal water supply reservoirs in Ghana. J. Ghana Sci. Ass. 6(1): 128-138.

DeZuane P. E. J. (1997). General or physical parameters. In Handbook of Drinking Water Quality. (P. E. J. DeZuane, ed.), pp.19-47. Van Nostrand Reinhold, New York.

Department for International Development (DFID) (1999). Assessment of environmental water quality standard. Final report. Water Engineering and Development Centre, Loughborough University, UK.

Dunne T. and Leopold, L. B. (1978). Chemical characteristics of water. In Water in Environmental Planning. (T. Dunne and L. B. Leopold, ed.), pp. 727-766. W. H. Freeman and Company, New York.

Hynes H. B. N. (1970). The ecology of running waters. Liverpool University Press. Liverpool. 555 pp.

Islam S. M. and Tanaka M. (2004). Impacts of pollution on coastal and marine ecosystems including coastal and marine fisheries and approach for management: a review and synthesis. Mar. Pollut. Bull., 48: 624-649.

Kondakis X. G., Makris N., Leotsinidis M., Prino M. and Papapetropoulos T. (1989). Possible health effects of high manganese concentration in drinking water. Arch. envir. Hlth 44(3): 175-178.

Kpekata A. E. and Biney C. A. (1979). The chemistry of the Densu lake between November 1976 and March 1978, 1-6 pp. In The Potential for Fishery in the Densu Weija Reservoir, Proceeding of Seminar. (A. L. Dassah and E. K. Abban, ed.) Technical Report 89. Institute of Aquatic Biology (CSIR), Accra, Ghana.

Larmie S. A. (1988). An application of QUA2E and QUAL2E-UNCAS Models to a water quality study of the Densu River in Southern Ghana. (MSc. Thesis.) Vrije University, Brussels, Belgium.

Livingstone D. A. (1963). Chemical composition of rivers and lakes. In Data of geochemistry (M. Fleischer, ed.) US Government Printing Office.

Marshall B. E. (1984). Lake Kariba (Zimbabwe/Zambia). In Status of African reservoir fisheries (J. M. Kapetsky and T. Petr, ed.), pp. 105-153. CIFA Technical Paper 10. FAO, Rome.

West African Journal of Applied Ecology - Volume 13 
McNeely R. N., Neimanis V. P. and Dwyer L. (1979). Water quality source book - A guide to water quality parameters. Environment Canada, Inland Waters Directorate, Water Quality Branch, Ottawa, Canada.

Meybeck M. and Helmer R. (1989). The quality of rivers: from prestine stage to global pollution. Palaeogeography, Palaeoclimatology, Palaeoe-cology (Global Planet Change Section) 75: 283-309.

Nukunya G. K. and Boateng E. O. (1979). Weija Dam Project An Evaluation/Study of Water Utilisation Behaviour and its Realated Socio-economic Impact. Report submitted to Canadian International Development Agency (CIDA).

Odei M. A. (1975). The prospects of some water borne diseases in the Area of the proposed Weija Dam Reservoir near Accra. Ghana J. Sci. 15: 219-224.

Ofori-Danson P. K. and Ntow W. J. (2005). Studies on the current state of the limno-chemistry and potential fish yield of Lake Volta (Yeji sector) after three decades of impoundment. Ghana J. agric. Sci. 38: 55-64.

Sangodoyin A. Y. and Sanyalou O. S. (1995). Land use pattern correlated with fresh water pollution in a developing environment. Envir. Educ. Info. 14(2): 163-170.

Straskaba M. and Tundisi J. G. (1999). Guidelines of Lake Management, vol. 9. Reservoir Water Quality Management. Lake Environment Committee Foundation, Shiga, Japan.

Stumm W. and Morgan J. J. (1981). Aquatic Chemistry. Wiley. New York. 780 pp.

Vanden Bossche, J.-P and Bernacsek, G. M. (1990). Source Book for the Inland Fishery Resources of Africa, vol 1. CIFA Technical Paper No 18/1. 240 pp.

Webb J. E. (1960). Biology in the tropics. Nature, 188: 617-619.

Wetzel R. G. (1983). Limnology, 2nd edn. W. B. Saunders Coy, Philadelphia, USA, 858 pp.

World Health Organization (WHO). (1984). Guidelines for Drinking Water Quality, vol. 1 and 2. World Health Organization, Geneva, Switzerland.

World Health Organization (WHO). (1993). Guidelines for Drinking Water Quality. World Health Organization, Geneva, Switzerland.

World Health Organization (WHO). (1996). Guidelines for Drinking Water Quality, vol. 2, 2nd edn. Health criteria and other supporting information.World Health Organization, Geneva, Switzerland.

World Health Organization (WHO). (2004). Guidelines for Drinking Water Quality, vol. 1, 3rd edn. World Health Organization, Geneva, Switzerland. 